\title{
Antimicrobial Ceramic Filters for Water Bio-Decontamination
}

\author{
Olga Ferreira ${ }^{1,2} \oplus$, Patrícia Rijo ${ }^{3,4}{ }^{\oplus}$, João Gomes ${ }^{2,5}{ }^{\oplus}$, Ricardo Santos ${ }^{6}$, Sílvia Monteiro ${ }^{6} \oplus$, Rita Guedes ${ }^{1}$, \\ Maria Luísa Serralheiro ${ }^{1} \mathbb{D}$, Marisa Gomes ${ }^{7}{ }^{\mathbb{D}}$, Luciana C. Gomes ${ }^{7}{ }^{\mathbb{D}}$, Filipe J. Mergulhão ${ }^{7} \mathbb{D}$ \\ and Elisabete R. Silva ${ }^{1,2, *(\mathbb{D})}$
}

1 BioISI-Biosystems \& Integrative Sciences Institute, Departamento de Química e Bioquímica, Faculdade de Ciências, Universidade de Lisboa, 1749-016 Lisboa, Portugal; orferreira@fc.ul.pt (O.F.); cpn.ritaguedes@gmail.com (R.G.); mlserralheiro@fc.ul.pt (M.L.S.)

2 CERENA-Centro de Recursos Naturais e Ambientais, Departamento de Civil, Instituto Superior Técnico, Universidade de Lisboa, Avenida Rovisco Pais 1, 1049-001 Lisboa, Portugal; igomes@deq.isel.ipl.pt

3 CBIOS-Research Center for Biosciences \& Health Technologies, Universidade Lusófona, Campo Grande 376, 1749-024 Lisboa, Portugal; p1609@ulusofona.pt

4 Instituto de Investigação do Medicamento (iMed.ULisboa), Faculdade de Farmácia da Universidade de Lisboa, Avenida Professor Gama Pinto, 1649-003 Lisboa, Portugal

5 Área Departamental de Engenharia Química, Instituto Superior de Engenharia de Lisboa (ISEL-IPL), Rua Conselheiro Emídio Navarro 1, 1959-007 Lisboa, Portugal

6 Laboratório de Análises, Instituto Superior Técnico, Universidade de Lisboa, Avenida Rovisco Pais 1, 1049-001 Lisboa, Portugal; ricardosantos@tecnico.ulisboa.pt (R.S.); silvia.monteiro@tecnico.ulisboa.pt (S.M.)

7 LEPABE-Laboratory for Process Engineering Environment, Biotechnology and Energy, Faculty of Engineering, University of Porto, Rua Dr. Roberto Frias, 4200-645 Porto, Portugal; marisagomes@fe.up.pt (M.G.); luciana.gomes@fe.up.pt (L.C.G.); filipem@fe.up.pt (F.J.M.)

check for

updates

Citation: Ferreira, O.; Rijo, P.; Gomes, J.; Santos, R.; Monteiro, S.; Guedes, R.; Serralheiro, M.L.; Gomes, M.; Gomes, L.C.; Mergulhão, F.J.; et al.

Antimicrobial Ceramic Filters for Water Bio-Decontamination. Coatings 2021, 11, 323. https://doi.org/ 10.3390/coatings11030323

Academic Editor:

Alessandro Pezzella

Received: 18 February 2021

Accepted: 8 March 2021

Published: 11 March 2021

Publisher's Note: MDPI stays neutral with regard to jurisdictional claims in published maps and institutional affiliations.

Copyright: (c) 2021 by the authors. Licensee MDPI, Basel, Switzerland. This article is an open access article distributed under the terms and conditions of the Creative Commons Attribution (CC BY) license (https:// creativecommons.org/licenses/by/ $4.0 /)$.
* Correspondence: ersilva@fc.ul.pt; Tel.: +351-217500991

Abstract: Bio-contamination of water through biofouling, which involves the natural colonization of submerged surfaces by waterborne organisms, is a global socio-economic concern, allied to premature materials bio-corrosion and high human health risks. Most effective strategies release toxic and persistent disinfectant compounds into the aquatic medium, causing environmental problems and leading to more stringent legislation regarding their use. To minimize these side effects, a newly nonbiocide-release coating strategy suitable for several polymeric matrices, namely polydimethylsiloxane and polyurethane (PU)-based coatings, was used to generate antimicrobial ceramic filters for water bio-decontamination. The best results, in terms of antimicrobial activity and biocide release, showed an expressed delay and a decrease of up to $66 \%$ in the population of methicillin-resistant Staphylococcus aureus bacteria on ceramic filters coated with polyurethane (PU)-based coatings containing grafted Econea biocide, and no evidence of biocide release after being submerged for 45 days in water. Biocidal PU-based surfaces were also less prone to Enterococcus faecalis biofilm formation under flow conditions with an average reduction of $60 \%$ after $48 \mathrm{~h}$ compared to a pristine PU-based surface. Biocidal coated filters show to be a potential eco-friendly alternative for minimizing the environmental risks associated with biofouling formation in water-based industrial systems.

Keywords: micro-foulers; ballast waters; cordierite monoliths; non-biocide release coating; dynamic biofilm assays; antimicrobial filtration

\section{Introduction}

Water is the most vital resource for all living forms on earth. However, surface water and groundwater are globally impacted by diverse pollutants where the presence of fecal bacteria (e.g., Escherichia coli, Enterococcus faecalis) is a good indicator of water contamination [1-3]. Furthermore, only less than $1 \%$ of the freshwater is drinkable, and, still, at least one billion people around the world do not have access to potable and microbiologicallysafe water [2]. Water is a vulnerable resource and its quality is a worldwide top-priority 
issue for suppliers, consumers, and regulatory bodies. Water storage and distribution systems, composed of diverse infrastructure networks, that transport water targeting several uses, are crucial to guarantee a safe water supply. Ballast waters from ships constitute a representative and increasing concern of water use. Those waters, stored in ships and often released in harbors, can, in the absence of any treatment, contaminate the surface waters by transferring microorganisms from one part of the world to another [4]. The presence of microorganisms and their interaction with those waterborne systems, namely the production of biofilms, can lead to serious economic penalties and health threats, which is enhanced by the current lack of control on their discharge, reinforced by the continuous increase at a global scale, of the shipping transport traffic, including transport in lakes and rivers, which is estimated to transfer about three to five billion tonnes of ballast water per year $[5,6]$.

The biofilm matrix is an aggregation of different types of biopolymers produced by microorganisms that are responsible for the integrity of a structural and functional biofilm $[7,8]$. The formation of a complex multispecies biofilm, always comprises a sequence of events over different length scales [5,9]. Studies also reported that biofilms provide the habitat for pathogenic microorganisms, such as Pseudomonas aeruginosa, Escherichia coli, or even multidrug resistant bacteria [10,11]. Most accepted stages of biofilm development on a surface $[12,13]$ comprise the primary adhesion of colonizers (planktonic microorganisms) in a conditioning film rich in organic matter, followed by a secondary adhesion of bacterial cells, with the production of extracellular polymeric substances, which act as nutrient concentration and storage promoters, as well as reactive transport barriers to chemical biocides. This secondary adhesion will further develop to a macrofouling level, depending on the physical-chemical and biological characteristics of the environment, which can be reached in just a few days or weeks. This is a phenomenon known as biofouling [14,15]. Biofouling is mostly composed of water, bacteria, suspended solids, and macro-foulants (e.g., algae and yeast/fungi), which, as a whole, are intensive promoters of biocorrosion [14], leading to premature equipment deterioration. Another issue associated with this natural phenomenon is its contribution to flow resistance in water system circuits (e.g., pipes and filters) as a result of biomass clogging effects and subsequent retrofitting consequences $[5,16]$. On the other hand, bio-detachment from biofilms is one of the least studied events in these systems. However, it is also one of the most concerning events, particularly in dynamic systems where hydrodynamics plays an important role. This may have severe detrimental impacts on water quality and safety, since it is a promotor of water bio-contamination and possible human waterborne diseases $[4,17,18]$ posing serious public health risks.

Several methodologies were developed, and new technologies were implemented in the search for solutions to mitigate this bio-burden $[1,6,19]$. One of the most addressed targets in antifouling strategies is the development of surfaces that are not readily colonized by microorganisms and are ideally easy to clean. To date, the most effective is the chemical disinfection by toxic agents or disinfectants, such as bactericides or oxidizing biocides, directly applied to inactivate microbial cells and to limit microbial regrowth and contamination, and are commonly combined with a prior filtration or separation. Among those, most conventional treatments are based on the use of chlorine dioxide disinfectants $[6,20]$. The success of disinfection practices led to the virtual elimination of the deadliest waterborne diseases in developed countries, particularly during the 1940s and 1950s, suppressing typhoid fever and cholera diseases [1]. Unfortunately, the by-products originating from the disinfection processes constitute themselves a concern. This is due to their intrinsic toxicity and ineffectiveness against biofilm development since the dead biomass can still serve as a substratum for new microorganism deposition and regrowth.

Additionally, stringent international regulations (e.g., Biocidal Products Directive (BPD) EU Regulation, 2012) were issued, limiting or even banning the use of the most effective employed biocidal agents and related products currently in the market. Alternative commercially available methods include filtration and UV treatment, which can also be 
an alternative eco-friendly cleaning process $[5,21]$, but it is expensive and fails to prevent some microorganisms' colonization (e.g., fungi), particularly on organic materials, such as polymers $[5,22]$.

There is, thus, a need for new non-toxic and long-lasting antifouling strategies in these waterborne systems. In this direction, we report an original antimicrobial non-biocide release strategy, able to provide antimicrobial monolithic ceramic filters through their surface protection with antifouling coating films containing grafted Econea biocide [23,24].

For this purpose, polydimethylsiloxane (PDMS) and polyurethane (PU)-based marine coatings were selected to confirm the feasibility of coated filters for the different polymeric matrices. PDMS-based coatings have been of increasing interest, not only due to their eco-friendly nature, as no biocidal agents are used in their formulations [25], but also due to their low surface energy and relatively higher elasticity (low Young's modulus), able to weaken the adhesion of organisms and promote their removal under dynamic conditions. However, these coatings also exhibit relatively low mechanical properties, becoming easily damaged (e.g., by cutting, tearing, puncturing) under more aggressive conditions [26], reducing their performance and service lifetime, making them fully effective only under dynamic conditions $[27,28]$. On the other hand, PU-based coatings provide relatively higher physical-mechanical properties, thermal stability, and chemical resistance, becoming preferred under more demanding conditions, such as those found in water treatment systems, but its antifouling action is still provided through the release of biocides [29].

The potential application of non-biocide release coatings as coated filters for biofouling prevention in both quasi-static and flow conditions is demonstrated for the first time in this work. Hydrodynamic conditions are crucial, since they may vary daily and seasonally from stagnation to high flow as demand varies [30], and these changes are reflected in the resultant biofilm. Furthermore, there are critical zones in piping or storage systems such as crevices, depressions, or dead-zones, which are difficult to clean due to limited access and where lower fluid velocities are found, making these places suitable for biofilm build-up [31]. According to the numerical simulations previously performed by the group [32], the flow rate chosen to operate the flow cell system in the present work $(300 \mathrm{~L} / \mathrm{h})$ reproduces the hydrodynamics of these critical zones where shear stress values around $0.25 \mathrm{~Pa}$ can be attained $[31,33]$.

\section{Materials and Methods}

\subsection{Monolithic Filters Coated with Biocide Non-Release Coatings}

Biocide non-release coatings were prepared following a prior developed methodology [23,24] in order to graft the booster Econea (4-bromo-2-(4-chlorophenyl)-5-(trifluoromethyl)-1H pyrrole-3-carbonitrile $>97 \%$ ) biocide (E), provided by Janssen PMP (Beerse, Belgium), in two representative commercial paints, a foul-release polydimethylsiloxane, X3-PDMS, (HEMPASIL X3+ 87500) and a polyurethane (PU), (Ref. F0038), both provided by Hempel A/S, Copenhagen, Denmark, and composed by two-component systems, comprising a base resin and curing agent: Hempasil Base 87509 and Crosslinker 98951 for the PDMS paint, and base F0032 and curing agent 95580 for the PU system. Briefly, an isocyanate-functional derivative (EM), possessing a grafting ability into polymeric compatible matrices, was obtained from the functionalization of the biocide with a diisocyanate reagent (Supplementary Figure S1). The biocidal coating formulations were further obtained through the addition and blending of a solution of the biocide derivative in 1-methyl-2-pyrrolidone (99.5\% Acros Organics, Geel, Belgium), at a solvent/biocide $(w / w)$ ratio of $0.48 / 0.23$, in the components of the paint at a base resin/curing agent $(w / w)$ ratios of 12.30/1.40 and 13.20/1.50 for the X3-PDMS and PU systems, respectively.

A second PDMS-based coating system (RTV-PDMS), known as a room-temperaturevulcanizing (RTV) polydimethylsiloxane (PDMS) coating (RTV11, MOMENTIVE, Waterford, NY, USA), was also included in the studies. This particular two-component coating system was selected for pre-screening antimicrobial bioassays, since it allows an evaluation of the single biocide influence in the coating behavior, avoiding, for instance, any potential 
overlapping or synergistic effects, which may occur for commercial paints, particularly the ones associated with the intrinsic foul-release properties of the X3-PDMS. However, these are only significant under specific dynamic conditions [24]. For the optimized RTV-PDMS formulations, a biocide solution in 1-methyl-2-pyrrolidone at a solvent/biocide $(w / w)$ ratio of $0.48 / 0.23$, and a base resin/curing agent ratio of $13.37 / 0.08$ were employed. The coating formulations were then used to coat filter samples $\left(1.5 \times 1.5 \times 2 \mathrm{~cm}^{3}\right)$, obtained by disc cutting from a cordierite-based commercial monolithic filter (200 cpsi) commonly applied in fluid purification industrial systems [34]. The filter samples were then cleaned with compressed air and coated with the coating formulations by using a conventional dipcoating methodology. For the PDMS-based formulations, and in accordance with coating components supplier recommendations, a prior coating of the filters was also carried out with a silicone-tie coat (Base XA17 and curing agent XA18, Hempel A/S, Copenhagen, Denmark) to guarantee the proper adhesion of the PDMS smooth coating matrices on the filters' surface.

The grafting methodology between the polymeric matrices (X3-PDMS and PU) with the isocyanate Econea derivative and the dip-coating procedure for the painting of the monolithic filters are illustrated in Figure 1.

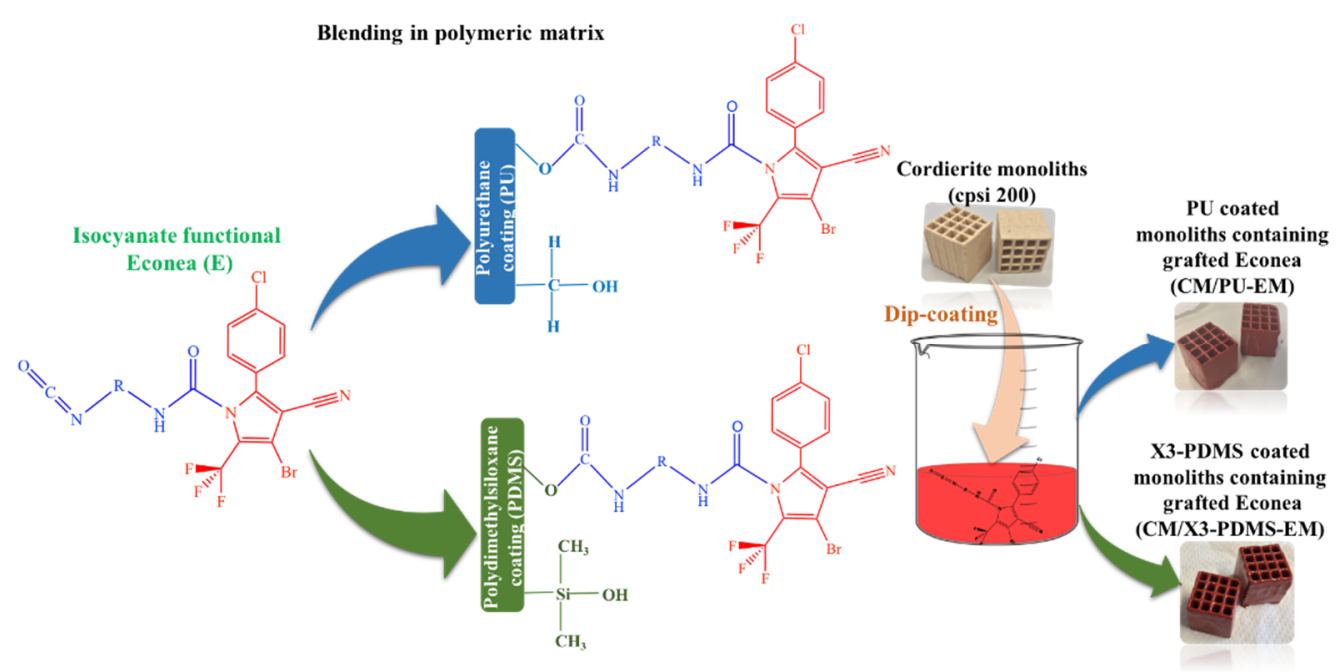

Figure 1. Eco-friendly strategy comprising the development of isocyanate-reactive biocides and their subsequent grafting in different representative polymeric matrices, polyurethane (PU)-based, and polydimethylsiloxane (X3-PDMS)-based paints to originate non-release antifouling coatings used to coat cordierite monolithic filters.

Coating formulations of the pristine polymeric matrices and containing incorporated Econea (E) biocide were also prepared to be used as controls and for comparative purposes. The pristine coatings preparation followed the suppliers' instructions, using base resin/curing agent $(w / w)$ ratios of 6.99/0.90, 7.52/0.84, and 17.83/0.11 for the X3-PDMS, PU, and RTV-PDMS systems, respectively. For the Econea biocide incorporation in those coatings, the addition and blending procedure was similar to the prior one described for the biocide derivative immobilization, using a solvent/biocide $(w / w)$ ratio of $0.48 / 0.23$, and base resin/curing agent ratios of 9.09/1.17, 6.90/0.79, and 13.66/0.09 for the X3-PDMS, PU, and RTV-PDMS systems, respectively.

\subsection{Structural Characterization and Antimicrobial Activity of Biocidal Agents}

The biocides structural characterization was performed by standard techniques such as Fourier Transform Infrared Spectroscopy (FTIR) and Nuclear Magnetic Resonance (NMR). The isocyanate-free content on the functional biocide derivative was determined by an adapted procedure from the standard ASTMD2572, already described in previous publications [24,35]. 
For the antimicrobial activity evaluation of both Econea biocide and its isocyanatefunctional derivative, direct contact and microdilution methodologies were used, as the following described.

\subsubsection{Antimicrobial Susceptibility by Direct Contact}

A direct contact methodology was used to assess the effect of the biocides on the microorganism's cultural growth. This contact was promoted by growing a pure culture of methicillin-resistant Staphylococcus aureus (MRSA) strain (ATCC 33591) at $36 \pm 1{ }^{\circ} \mathrm{C}$ in Tryptic Soy Broth (TSB) (Becton Dickinson, Franklin Lakes, NJ, USA) until the exponential phase. Furthermore, $100 \mu \mathrm{L}$ of this culture were spread on Tryptic Soy Agar (TSA) (Biokar, Allonne, France) plates. Each of the prepared plates was further covered with the biocide samples in the powder state and incubated at $37^{\circ} \mathrm{C}$ for $48 \mathrm{~h}$. After incubation, plates were checked for the presence of bacterial growth.

2.2.2. Microdilution Method-Minimum Inhibitory Concentrations (MICs) and Minimum Bactericidal Concentrations (MBCs)

Minimal inhibitory concentrations (MIC) were determined by the broth dilution method, following the recommendations of the Clinical and Laboratory Standards Institute [36] and against the Gram-positive bacteria Staphylococcus aureus (ATCC 25923), Enterococcus faecalis (ATCC 29212), and MRSA (CIP 106760). Stock solutions of Econea (E) and isocyanate-functional derivative $(\mathrm{EM})(10 \mathrm{mg} / \mathrm{mL})$ were prepared in dimethyl sulfoxide (DMSO) and kept at $4 \pm 1{ }^{\circ} \mathrm{C}$.

In each well of a $96 \mathrm{U}$-shaped microplate, $100 \mu \mathrm{L}$ of Mueller-Hilton (MH) broth were introduced. In the first well, $100 \mu \mathrm{L}$ of $\mathrm{E}$ and $\mathrm{EM}$ were added at a concentration of $1 \mathrm{mg} / \mathrm{mL}$ (diluted from the appropriate stock solution). The former (E) acts as a positive control. A two-fold serial broth microdilution within the concentration range of $500-0.49 \mu \mathrm{g} / \mathrm{mL}$ was further performed using a multichannel micropipette. In each well, $10 \mu \mathrm{L}$ of a standardized bacterial suspension equivalent to $0.5 \mathrm{McF}$ arland of each microorganism was placed. Finally, the microplates were incubated at $37^{\circ} \mathrm{C}$ for $24 \mathrm{~h}$. The microbial growth was evaluated using an absorbance microplate reader (Multiskan FC Thermo Scientific, Loughborough, UK) at $620 \mathrm{~nm}$, and the MIC was taken as the lowest concentration of the biocide that inhibited the visible growth of microorganisms by comparison with the controls.

The MBCs values were also evaluated to verify the bactericidal/bacteriostatic properties of the biocides against MRSA bacteria. For this purpose, after MIC determinations and for each set of wells that did not show any growth of MRSA bacteria, a loopful of broth was collected and inoculated on sterile MH agar. The MBC was taken as the lowest concentration of the biocide that killed $99.9 \%$ of the initial inoculum after $24 \mathrm{~h}$ of incubation at $37^{\circ} \mathrm{C}$.

Three independent bioassays were performed for all tested microorganisms and methodologies.

\subsection{Antimicrobial Potential of Developed Biocidal Coatings}

Prior to the evaluation of the antimicrobial potential of the coated filters, a screening of the biocidal coatings' antimicrobial susceptibility against E. faecalis (ATCC 29212) and MRSA (ATCC 33591) was performed by a direct contact methodology. Briefly, in a sterile environment, the bottom of $90 \mathrm{~mm}$ Petri dishes (Greiner bio-one, Frickenhausen, Germany) was coated with Econea-based polymeric coatings (X3-PDMS, PU, and RTV-PDMS), comprising biocide contents ranging from 0.56 to $1.30 \mathrm{wt} . \%$ for the PDMS-based coating and from 2 to $3 \mathrm{wt} . \%$ for the PU-based coatings. On each coated Petri dish, $20 \mathrm{~mL}$ of TSA (Biokar, Allonne, France) were poured and left to solidify. After solidification, the bacteria were spread into the agar plate surfaces and incubated for $48 \mathrm{~h}$ at $36 \pm 1{ }^{\circ} \mathrm{C}$. Reaching the incubation period, the bacterial growth extension on the coating surface was visually evaluated as a yellowish, opaque film formation, and its extension in the tested area registered. 


\subsection{Biocide Grafting Efficacy on Coated Monolithic Filters}

After the successful development of bioactive coatings, the most promising were used for the first time to coat monolithic filters. The biocide immobilization efficacy on the monolithic filters coated with X3-PDMS and PU-based coatings, containing either incorporated Econea (CM/X3-PDMS-E and CM/PU-E) and grafted Econea (CM/X3-PDMS$\mathrm{EM}$ and $\mathrm{CM} / \mathrm{PU}-\mathrm{EM})$, was evaluated through a leaching test methodology adapted from the standards of OECD 313-2007 [37] and ISO 15181 [38]. The leaching tests comprise the submersion of coated filters in distilled water $(250 \mathrm{~mL})$ for at least 45 days, under continuous stirring ( $\cong 200 \mathrm{rpm})$. The test was performed with an average $\mathrm{pH}$ of $7 \pm 1$, and temperatures ranging from 20 to $24^{\circ} \mathrm{C}$. The obtained leaching waters were then filtered and stored in the refrigerator for at least 30 days to ensure the complete degradation of the potentially released Econea into a more stable compound in water, which allows its further accurate quantification in leaching waters through ultra-high performance liquid chromatography coupled to tandem mass spectrometry (UHPLC-MS/MS). The chromatographic analyses were conducted by using an ELUTE autosampler UHPLC (Bruker, Bremen, Germany), using an Intensity Solo 2 C18 RP column (100 $\mathrm{mm} \times 2.1 \mathrm{~mm}$, $2.0 \mu \mathrm{m}$, Bruker, Bremen, Germany). A volume of $5 \mu \mathrm{L}$ was injected (auto injector) into the system using a gradient composed of water (Milli-Q) with $0.1 \%$ formic acid (eluent A, 99.5+\%, Optima ${ }^{\circledR}$ LC/MS grade 50ML Fisher Chemical, Porto Salvo, Portugal) and Acetonitrile (ACN, Optima LC/MS 2.5 L Fisher Chemical, Porto Salvo, Portugal) with $0.1 \%$ formic acid (eluent B), as follows: $0 \mathrm{~min}-95 \% \mathrm{~A}, 1.5 \mathrm{~min}-95 \% \mathrm{~A}, 13.5 \mathrm{~min}-25 \% \mathrm{~A}$, $18.5 \mathrm{~min}-0 \% \mathrm{~A}, 21.5 \mathrm{~min}-0 \% \mathrm{~A}, 23.5 \mathrm{~min}-95 \% \mathrm{~A}$, and $30 \mathrm{~min}-95 \% \mathrm{~A}$, with a flow rate of $0.250 \mathrm{~mL} / \mathrm{min}$ and a column temperature of $35^{\circ} \mathrm{C}$.

For mass spectrometry, an Impact II QToF (Bruker, Bremen, Germany) was used. The method consisted of MS/MS scans, in both positive and negative ionization modes, in the 50-1500 m/z range. The capillary voltage was set to 3500 and $4000 \mathrm{~V}$, for the negative and positive ionization modes, respectively, and the collision cell energy to $5.0 \mathrm{eV}$. The end plate offset was set to $500 \mathrm{~V}$, the dry gas $\left(\mathrm{N}_{2}\right)$ was kept at $8.0 \mathrm{~L} / \mathrm{min}$ at $200{ }^{\circ} \mathrm{C}$, and the nebulizer gas $\left(\mathrm{N}_{2}\right)$ was set to 2.0 bars. Internal calibration was performed on the high precision calibration mode (HPC) with a solution of $250 \mathrm{~mL}$ of ultra-pure water (Milli-Q Water Purification System, Merck Millipore, Burlington, MA, USA), $250 \mathrm{~mL}$ of isopropanol (Isopropanol LC/MS OPTIMA Grade 1 L Fisher Chemical, Porto Salvo, Portugal), $750 \mu \mathrm{L}$ of acetic acid (Glacial HPLC, Fisher Chemical, Porto Salvo, Portugal), $250 \mu \mathrm{L}$ of formic acid, and $0.5 \mathrm{~mL}$ of sodium hydroxide (Sodium hydroxide, for analysis, pellets, Fisher Chemical, Porto Salvo, Portugal) solution 1N. The data was acquired through the DataAnalysis 4.4 software (Bruker, Bremen, Germany).

For the leaching water, at least two replicates were performed by UHPLC-MS/MS.

\subsection{Water Bio-Decontamination Potential of Non-Biocide-Release-Coated Substrates}

\subsubsection{Antimicrobial Susceptibility of Coated Monolithic Filters}

For the antimicrobial susceptibility evaluation of the coated monolithic filters at quasistatic conditions ( $\leq 200 \mathrm{rpm}$ ), a time-kill test was performed to assess their bioactivity as a function of time against MRSA. The method includes the monitoring of the bacterial growth of a known population $\left(10^{6} \mathrm{CFU} / \mathrm{mL}\right)$ of MRSA (CIP 106760) in the absence and presence of immersed uncoated and coated monolithic filters.

Aliquots of bacteria medium were taken every $60 \mathrm{~min}$ of testing and monitored by absorbance measurements at $620 \mathrm{~nm}$ in a Microplate Reader (Multiskan FC Thermo Scientific, Loughborough, UK) to evaluate the bacterial growth population, expressed by absorbances, until reaching a steady bacterial content. The control consisted of the same buffer solution containing the bacteria without the monolithic filter. Three independent bioassays were performed for the tested microorganism. 
The data of bioassays were analyzed non-parametrically using the Friedman test to detect statistical differences in the bacterial absorbance across the monolithic filters. Results were reported as a mean \pm standard deviations (SDs) and considered statistically different for a confidence level greater than $95 \%(p<0.05)$. The data were analyzed using statistical software (IBM SPSS Statistics, version 26).

\subsubsection{Biofilm Formation on Coated Substrates under Dynamic Conditions}

In water treatment systems, severe conditions are employed (e.g., UV light, aggressive chemicals, flow stresses), and a PDMS-based coating is not the most suitable for this specific use, mostly due to its relatively low mechanical properties, becoming easily damaged (e.g., by cutting, tearing, and puncturing) [26]. For that reason and to prove the water biodecontamination concept in conditions closer to the real ones, the polyurethane coating formulations were used to coat acrylic prototypes $(2 \mathrm{~cm} \times 1 \mathrm{~cm})$ and the antifouling effect of these surfaces against $E$. faecalis was evaluated at hydrodynamic conditions prevailing in water-based industrial systems.

An overnight culture of E. faecalis (ATCC 29212) was obtained by inoculation of $500 \mu \mathrm{L}$ of a glycerol stock (kept at $-80^{\circ} \mathrm{C}$ ) to a total volume of $200 \mathrm{~mL}$ of TSB [39] and incubation at $30{ }^{\circ} \mathrm{C}$ with orbital agitation (AGITORB 200, Aralab, Portugal). TSB was used as a culture medium for dynamic assays given its relevance in the development of biofilms in industrial systems [39].

The culture was then harvested by centrifugation (10 min, $3202 \mathrm{~g}$ ) and the pellets were resuspended in fresh TSB to reach a final optical density (OD) of 0.23 at $620 \mathrm{~nm}$, which corresponds to $7.6 \times 10^{7} \mathrm{CFU} / \mathrm{mL}$.

A semi-circular flow cell system was used for these assays to simulate the formation of biofilms in industrial pipes [32]. It is composed of a recirculating tank, a vertical flow cell, and peristaltic and centrifugal pumps. This system allows the sampling of individual coupons placed in the vertical flow cell, with surface materials glued to them, without disturbing the biofilm formed on the other coupons [40]. The bacterial suspension was circulated in the system at a flow rate of $300 \mathrm{~L} / \mathrm{h}$ in order to obtain an average wall shear stress of $0.25 \mathrm{~Pa}$ that can be found in critical piping zones (e.g., crevices, corners, joints, and valves [32]). The recirculating tank was continuously fed with sterile TSB $(0.025 \mathrm{~L} / \mathrm{h})$ and biofilms were formed on pristine PU coatings (control), PU coating with incorporated Econea (PU-E), and PU coating with grafted Econea (PU-EM). The temperature was kept at $30{ }^{\circ} \mathrm{C}$ and the antibiofilm properties of these coatings were evaluated after $48 \mathrm{~h}$ by determining colony forming units (CFUs). The biofilms were mechanically detached (by vortexing) from the surfaces and homogenized in $5 \mathrm{~mL}$ of sterile saline solution $(8.5 \mathrm{~g} / \mathrm{L}$ $\mathrm{NaCl}$ ). To assess cell counts, 10-fold serial dilutions of the biofilm suspensions were prepared, spread on plate count agar (PCA, Merck, Darmstadt, Germany), and incubated at $30{ }^{\circ} \mathrm{C}$ for $24 \mathrm{~h}$ for colony enumeration. Biofilm cell counts are presented as CFU per unit area of surface $\left(\mathrm{CFU} / \mathrm{cm}^{2}\right)$.

Two independent experiments with five technical replicates of each surface were performed. Paired $t$-test analyses were done to evaluate if statistically significant differences were obtained between the two PU modified coatings (PU-E and PU-EM) and pristine PU. Results were reported as mean \pm standard deviation (SD) and considered statistically different for a confidence level greater than $99 \%(p<0.01)$.

\section{Results and Discussion}

\subsection{Structural Characterization and Antimicrobial Activity of Biocidal Agents}

The Econea biocide was successfully functionalized with $4,4^{\prime}$-methylene diphenyl diisocyanate (MDI) (Supplementary Figure S1) and its structure were confirmed by FTIRATR and NMR, as reported in previous publications [23,24,35], with conversions as high as $95 \% \pm 5 \%$ and a free isocyanate content average in the isocyanate-functional Econea derivative (EM) of $9 \pm 2$ wt.\%. 
The antimicrobial activities of Econea (E) and its isocyanate-functional derivative (EM) were evaluated against methicillin-resistant Staphylococcus aureus (MRSA) (ATCC 33591) by performing direct contact bioassays. The MRSA growth could be visually identified by a yellowish, opaque surface on the TSA medium, and the biocides that were in direct contact with the medium covered with bacteria could be identified as a dispersed powder (Supplementary Figure S2). The antimicrobial activity of the tested biocides was confirmed by the reduction of the yellowish opaque surface area on the TSA surface medium and the following order was obtained in terms of bacterial growth: MRSA culture $>$ Econea biocide $(\mathrm{E})>$ functional Econea derivative (EM). These results confirmed the antimicrobial potential of the biocide Econea (E) and its isocyanate-functional derivative (EM) against MRSA bacteria (Supplementary Figure S2). However, a more pronounced effect was obtained for EM, which can be associated with the dispersion effect of the biocide on the culture media, since, for the biocidal agent E, higher dispersion of the biocide along the MRSA culture media was obtained, whereas, for the EM, at a similar content, some agglomeration occurred, promoting a higher local concentration of the biocide, which was expressed by an increased antimicrobial effect on the tested bacteria media (Supplementary Figure S2c). This agglomeration of the Econea derivative is inherent to its isocyanate group, which is highly reactive with any active hydrogen-containing molecules [41], including the urea found in the EM derivative or formed by its reaction with water (moisture), which is impossible to remove completely during bioassays, and which promotes the self-reaction of the isocyanate-EM derivative and subsequent agglomeration.

From the MIC values of the biocides obtained against $S$. aureus and E. faecalis bacteria and a selected resistant bacterium, MRSA (CIP 106760), the E and EM biocides showed similar MIC values of $3.91 \mu \mathrm{g} / \mathrm{mL}$ against $S$. aureus and E. faecalis, but different for MRSA, with MIC values of 0.49 and $3.91 \mu \mathrm{g} / \mathrm{mL}$, respectively. These values suggest that the Econea biocide has a significantly higher antimicrobial activity (eight-fold) against MRSA when compared with its isocyanate derivative (EM), showing that the intrinsic structural bioactivity of $\mathrm{E}$ was affected by the derivatization reaction. However, a MIC value of $3.91 \mu \mathrm{g} / \mathrm{mL}$ is still considered a potential antimicrobial activity against MRSA bacterium, which encouraged its use for the generation of non-biocide-release protective coatings. Additionality, MBC assays were performed to E and EM biocides against MRSA bacteria (Supplementary Figure S3) in order to address the bacteriostatic and bactericidal properties of the biocides. Relatively high MBC values, $15.64 \mu \mathrm{g} / \mathrm{mL}$ (E) and $125 \mu \mathrm{g} / \mathrm{mL}$ (EM), were obtained for the biocides, expressed by their MBC/MIC ratios, 31.92 (E) and 31.97 (EM), which is a clear indicator of bacteriostatic properties of these biocides against MRSA bacteria, since MBCs exceed four-fold the MICs values, being in accordance with French [42].

\subsection{Biocidal Coating Formulations}

Several trials and iterative formulations of the polydimethylsiloxane (PDMS) and polyurethane (PU) coating formulations were tested, including at different biocide contents. The optimized formulations listed in Table 1 were then evaluated in terms of their antimicrobial potential, particularly when used as a protective coating on monolithic ceramic filters. The RTV-PDMS coating was exclusively used for the pre-screening bioassays. 
Table 1. Polymeric coating formulations containing either incorporated or grafted Econea biocide, and the respective pristine coating's controls (free of biocide).

\begin{tabular}{|c|c|c|c|c|c|}
\hline $\begin{array}{c}\text { Coating } \\
\text { Formulation } 1\end{array}$ & $\begin{array}{l}\text { Polymeric } \\
\text { Matrix }\end{array}$ & $\begin{array}{c}\text { Biocide } \\
\text { Immobilization }\end{array}$ & $\begin{array}{l}\text { Base Resin/Curing } \\
\text { Agent Ratio (w/w) }\end{array}$ & $\begin{array}{l}\text { Solvent/Biocide } \\
\text { Ratio }(w / w)^{2}\end{array}$ & $\begin{array}{l}\text { Biocide Content in } \\
\text { Wet Formulation } \\
\text { (wt.\%) }\end{array}$ \\
\hline \multicolumn{6}{|c|}{ Polymeric coatings formulations } \\
\hline X3-PDMS (control) & PDMS & - & 7.74 & - & - \\
\hline X3-PDMS/E & PDMS & Incorporation & 7.77 & 1.19 & $0.58 \pm 0.01$ \\
\hline X3-PDMS/EM & PDMS & Grafting & 7.36 & 1.72 & $0.60 \pm 0.01$ \\
\hline PU (control) & PU & - & 8.61 & - & - \\
\hline $\mathrm{PU} / \mathrm{E}$ & PU & Incorporation & 9.23 & 1.34 & $2.06 \pm 0.02$ \\
\hline PU/EM & PU & Grafting & 9.03 & 1.17 & $1.96 \pm 0.02$ \\
\hline \multicolumn{6}{|c|}{ Polymeric coatings formulations for pre-screening bioassays } \\
\hline X3-PDMS (control) & PDMS & - & 7.92 & - & 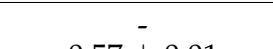 \\
\hline X3-PDMS/E & PDMS & Incorporation & $\begin{array}{l}7.92 \\
8.94\end{array}$ & $\begin{array}{l}2.28 \\
2.09\end{array}$ & $\begin{array}{l}0.57 \pm 0.01 \\
1.31 \pm 0.01\end{array}$ \\
\hline X3-PDMS/EM & PDMS & Grafting & $\begin{array}{l}8.86 \\
8.39\end{array}$ & $\begin{array}{l}1.60 \\
1.91\end{array}$ & $\begin{array}{l}0.59 \pm 0.01 \\
1.24 \pm 0.01\end{array}$ \\
\hline PU (control) & PU & - & 9.31 & - & $\begin{array}{c}1.2 x+0.01 \\
-\end{array}$ \\
\hline PU/EM & PU & Grafting & $\begin{array}{l}9.27 \\
9.21\end{array}$ & $\begin{array}{l}2.79 \\
2.79\end{array}$ & $\begin{array}{l}1.96 \pm 0.02 \\
3.03 \pm 0.02\end{array}$ \\
\hline $\begin{array}{l}\text { RTV-PDMS } \\
\text { (control) }\end{array}$ & PDMS & - & 162.11 & - & $\begin{array}{c}0.00+0.02 \\
-\end{array}$ \\
\hline RTV-PDMS/E & PDMS & Incorporation & 151.76 & 1.92 & $1.36 \pm 0.01$ \\
\hline RTV-PDMS/EM & PDMS & Grafting & 190.97 & 2.27 & $1.32 \pm 0.01$ \\
\hline
\end{tabular}

\subsubsection{Antimicrobial Potential of Developed Biocidal Coatings}

Antimicrobial activities of PDMS-based and PU-based coatings containing either Econea (PDMS-E) and grafted Econea (PDMS-EM, PU-EM) against E. faecalis (ATCC 29212) and MRSA (ATCC 33591) were obtained.

From the bacterial growth responses obtained, expressed by a yellowish opaque film, the contact of Gram-positive bacteria E. faecalis and MRSA with the PDMS-based coatings (the red-colored X3-PDMS and the white-colored RTV-PDMS coatings containing incorporated Econea (E) and grafted Econea (EM)) affected their normal growth, whereas no significant effect was observed when in contact with the reference coating without biocide (Pristine X3-PDMS and Pristine RTV-PDMS) (Figure 2). These results are indicative of inhibitory effects by the biocidal coatings on the growth of MRSA. In addition, for the PDMS biocide coating containing the highest biocide content (1.30 wt.\%), a slightly higher inhibitory effect, expressed by a lesser extent of the yellowish opaque film on the coated Petri dish, was observed, suggesting a content effect on the action of the antimicrobial coatings.

Similar behavior was obtained for the biocidal PU-based coatings where the inhibitory growth outcomes against MRSA of the PU coating containing grafted Econea (PU-EM), Supplementary Figure S4, showed a more pronounced effect for higher biocide contents (3 wt.\%), whereas no significant inhibition was observed on the PU-based coating containing grafted Econea against the tested bacterium E. faecalis (Supplementary Figure S4). These results suggest that higher biocide contents in the formulations can promote improvement in the final antimicrobial properties, but they are also related to the intrinsic bioactivity of the biocide to a specific bacterium. In the case of E. faecalis, the bioactivity of the Econea biocide expressed in MIC values was relatively low against this bacterium $(3.91 \mu \mathrm{g} / \mathrm{mL})$ when compared with its MIC against the MRSA bacterium $(0.49 \mu \mathrm{g} / \mathrm{mL})$, suggesting that a higher biocide content would be needed to enhance the inhibition effect.

Overall, these results confirm the antimicrobial potential of the biocidal coating formulations, as well as the maintenance of the intrinsic bioactivity of the biocides when incorporated or grafted into polymeric-coating matrices. 


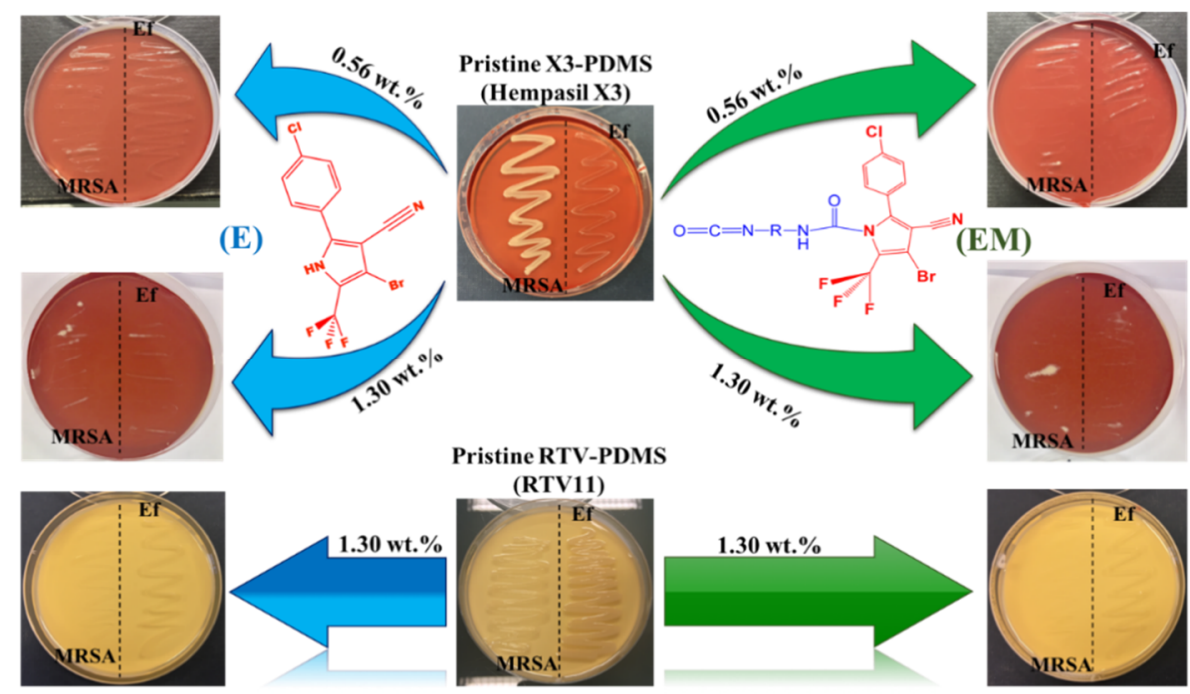

Figure 2. Antimicrobial susceptibility against MRSA and E. faecalis (Ef) of polydimethylsiloxane (PDMS)-based coatings, X3-PDMS, and RTV-PDMS, containing incorporated Econea, E (left side), and grafted Econea, EM (right side), at different biocide contents, $0.56 \mathrm{wt} . \%$ and $1.30 \mathrm{wt} . \%$.

\subsubsection{Biocide Grafting Efficacy on Coated Monolithic Filters}

To confirm whether the Econea biocide grafting was effective in the different polymericbased coating matrices (X3-PDMS and PU), optimized coating formulations were used to coat monolithic ceramic filters, and the biocide release from the coatings into the water (leaching waters obtained after submersion tests of 45 days) was evaluated by UHPLCMS/MS. These analyses, performed either in the negative and positive ionization modes (Supplementary Figure S5a,b), allowed the identification of 3-bromo-5-(4-chlorophenyl)-4cyano-1H-pyrrole-3-carboxylic acid (BCCPCA) in the leaching waters (Table 2 and Supplementary Figure S6). Nevertheless, the negative mode seemed to be more suitable for the analysis of these samples and, therefore, it was selected for the subsequent quantification of the leached compound. This BCCPCA (Econea degradation by-product [43]), was found in leaching waters of the PDMS-based filters containing incorporated (CM/X3-PDMS-E) or grafted Econea (CM/X3-PDMS-EM), as well as for the PU-based filter containing incorporated Econea (CM/PU-E). For the PU-based filter containing grafted Econea (CM-PU-EM), no leached compounds were detected.

Table 2. Identification of a leached compound from monoliths coated with polydimethylsiloxane (X3-PDMS) and polyurethane (PU) coatings containing incorporated (X3-PDMS-E and PU-E) and grafted Econea (X3-PDMS-EM and PU-EM), by UHPLC-MS/MS in negative $\left([\mathrm{M}-\mathrm{H}]^{-}\right)$and positive $\left([\mathrm{M}+\mathrm{H}]^{+}\right)$ESI modes. The compound was identified by the retention time $(\mathrm{Rt})$.

\begin{tabular}{|c|c|c|c|c|c|c|}
\hline $\begin{array}{l}\text { Coated Monolith } \\
\text { Filters (CM) }^{1}\end{array}$ & Rt (min) & {$[\mathbf{M}]$} & {$[\mathbf{M}-\mathbf{H}]^{-} /[\mathbf{M}+\mathbf{H}]^{+}$} & $\begin{array}{c}\text { Error } \\
(\Delta \mathrm{ppm})\end{array}$ & Formula & $\begin{array}{l}\text { Proposed } \\
\text { Compound }\end{array}$ \\
\hline \multicolumn{7}{|c|}{ ESI negative mode } \\
\hline CM/X3-PDMS-E ${ }^{-}$ & 11.6 & 323.9296 & 322.9220 & 2.6 & $\mathrm{C}_{12} \mathrm{H}_{6} \mathrm{BrClN}_{2} \mathrm{O}_{2}$ & ВССРСА \\
\hline CM/X3-PDMS-EM ${ }^{-}$ & 11.4 & 323.9296 & 322.9239 & -3.3 & $\mathrm{C}_{12} \mathrm{H}_{6} \mathrm{BrClN}_{2} \mathrm{O}_{2}$ & ВССРСА \\
\hline $\mathrm{CM} / \mathrm{PU}_{-\mathrm{E}^{-}}$ & 11.3 & 323.9296 & 322.9232 & -1.1 & $\mathrm{C}_{12} \mathrm{H}_{6} \mathrm{BrClN}_{2} \mathrm{O}_{2}$ & ВССРСА \\
\hline $\mathrm{CM} / \mathrm{PU}_{-\mathrm{EM}^{-2}}$ & - & - & - & - & - & - \\
\hline
\end{tabular}


Table 2. Cont.

\begin{tabular}{|c|c|c|c|c|c|c|}
\hline $\begin{array}{l}\text { Coated Monolith } \\
\text { Filters (CM) }^{1}\end{array}$ & Rt (min) & {$[\mathbf{M}]$} & {$[\mathbf{M}-\mathbf{H}]^{-} /[\mathbf{M}+\mathbf{H}]^{+}$} & $\begin{array}{c}\text { Error } \\
(\Delta \text { ppm })\end{array}$ & Formula & $\begin{array}{l}\text { Proposed } \\
\text { Compound }\end{array}$ \\
\hline \multicolumn{7}{|c|}{ ESI positive mode } \\
\hline CM/X3-PDMS-E ${ }^{+}$ & 11.2 & 323.9296 & 324.9376 & -0.6 & $\mathrm{C}_{12} \mathrm{H}_{6} \mathrm{BrClN}_{2} \mathrm{O}_{2}$ & ВССРCA \\
\hline $\mathrm{CM} / \mathrm{X} 3-\mathrm{PDMS}-\mathrm{EM}^{+} 2$ & - & - & - & - & $-12-0$ & - \\
\hline $\mathrm{CM} / \mathrm{PU}-\mathrm{E}^{+2}$ & - & - & - & - & - & - \\
\hline $\mathrm{CM} / \mathrm{PU}-\mathrm{EM}^{+} 2$ & - & - & - & - & - & - \\
\hline
\end{tabular}

${ }^{1} \mathrm{CM}-$ Coated Monolith filter. X3-PDMS-Hempasil X3+, a polydimethylsiloxane (PDMS) based paint. PU—Hempel F0038 polyurethanebased paint. E-Econea. EM-Isocyanate-functional Econea derivative. BCCPCA-Degradation compound of Econea biocide. Samples with a minus/plus superscript were analyzed in the negative and positive modes. ${ }^{2}$ For these samples, no significant compound amount was detected in the respective leaching waters.

From the data collected by the UHPLC-MS/MS analyses in an ESI negative mode, it was possible to quantify the total Econea biocide released from the coated filters (Table 3), which showed a substantially higher biocide release, $22.96 \mathrm{wt} . \%$ of the total Econea content in the coating, from the CM/X3-PDMS-E-coated filter, containing incorporated Econea, when compared with the CM/X3-PDMS-EM filter containing grafted Econea with a biocide release as high as $3.32 \mathrm{wt} . \%$. These results show the effectiveness of the biocide grafting in the CM/X3-PDMS-EM filter, achieving a 9.22-fold reduction in the biocide leaching $(\mathrm{mg} / \mathrm{L})$, resulting in a decrease in the average leaching rate of $2.67 \mu \mathrm{g} /$ day within 45 days, when compared to the average leaching rate of $24.59 \mu \mathrm{g} /$ day obtained for the CM/X3PDMS-E filter.

Table 3. Detected compound by UHPLC-MS/MS analyses in 45 days of leaching waters obtained from submerged monolithic-coated filters with biocidal polydimethylsiloxane (PDMS) and polyurethane (PU)-based coatings, prepared by direct incorporation of the biocide, CM/X3-PDMS-E and CM/PU-E, or by biocide grafting, CM/X3-PDMS-EM and $\mathrm{CM} / \mathrm{PU}-\mathrm{EM}$.

\begin{tabular}{|c|c|c|c|c|}
\hline \multirow{2}{*}{ Coated Monolithic Filters ${ }^{1}$} & \multirow{2}{*}{ Biocide Content (mg) } & \multicolumn{2}{|c|}{$\begin{array}{l}\text { Concentration in Leaching Waters } \\
\text { (45 days) }\end{array}$} & \multirow{2}{*}{$\begin{array}{c}\text { Econea Biocide } \\
\text { Leached from Coated } \\
\text { Filters (wt.\%) }\end{array}$} \\
\hline & & $\begin{array}{l}\text { BCCPCA } \\
\text { mg/L }\end{array}$ & $\begin{array}{c}\text { Econea }^{2} \\
\mathrm{mg} / \mathrm{L}\end{array}$ & \\
\hline CM/X3-PDMS & - & - & - & - \\
\hline CM/X3-PDMS-E & 4.82 & 4.12 & 4.43 & 22.96 \\
\hline CM/X3-PDMS-EM & 3.62 & 0.45 & 0.48 & 3.32 \\
\hline $\mathrm{CM} / \mathrm{PU}$ & - & - & - & - \\
\hline CM/PU-E & 15.04 & 0.88 & 0.95 & 1.57 \\
\hline CM/PU-EM & 13.79 & 0 & 0 & 0 \\
\hline
\end{tabular}

${ }^{1} \mathrm{CM}-$ Cordierite Monolithic filter. X3-PDMS—Hempasil X3+, a polydimethylsiloxane (PDMS) based paint. PU—Hempel F0038 polyurethane-based paint. E-Econea. EM-Isocyanate-functional Econea derivative. ${ }^{2}$ Econea concentration calculated considering the average amount of its degradation by-product (BCCPCA) in the leaching waters.

Moreover, from the filter coated with PU-based coating containing incorporated Econea (CM/PU-E), only $1.57 \mathrm{wt} . \%$ of Econea was leached from the coating. Improvements upon the biocide grafting strategy were still possible since, for the CM/PU-EM, no leached biocidal compound derivative was detected. This successful immobilization is associated with the isocyanate function of the Econea derivative. This function is compatible with polyurethane systems as they already contain isocyanate-based compounds, usually in the curing component of paint formulations, and which, together with a polyol-based component, regulates the formation of the polyurethane polymer matrix. The composition of these components typically contains additional additives to ensure their final function, such as the adhesion, wettability, or the color of paints. However, their final composition is not fully disclosed by suppliers for confidentiality reasons. 


\subsection{Potential of Non-Biocide-Release-Coated Filters for Waterborne Bio-Decontamination}

3.3.1. Antimicrobial Susceptibility of Coated Monolithic Filters

For the potential antifouling purpose application, it is crucial to study the bioactivity of the coatings when applied to the ceramic materials in close to real conditions. For this purpose, the antimicrobial activity of coated filters, against one of the most aggressive resistant bacteria, MRSA, was evaluated as a function of time through a time-kill methodology.

The monoliths coated with biocidal polydimethylsiloxane (PDMS) coatings containing incorporated (CM/X3-PDMS-E) and grafted (CM/X3-PDMS-EM) Econea showed a high inhibition of bacterial growth when compared to the growth of free bacteria or even with the filter coated with the pristine PDMS coating (CM/X3-PDMS) (Figure 3), revealing an auspicious antimicrobial activity for the monolithic filters coated with X3-PDMS-based coatings, containing either incorporated (CM/X3-PDMS-E) or grafted Econea (CM/X3PDMS-EM) (Figure 3). A slight increase in bacterial growth was also observed for the filter coated with pristine PDMS coating (CM/X3-PDMS) relative to the free bacteria growth curve. This behavior confirms the high susceptibility of bacteria to physically adsorb on PDMS-based surfaces [44,45], which is an effect that is clearly overcome by the biocidal coated filters. Furthermore, prior work has also confirmed that the bacteriostatic properties intrinsic to the Econea biocide and its derivative for the tested bacteria are also inferred on coatings, upon their effective immobilization [35], thus, promoting the minimization of the selective pressure on bacteria to develop resistance to treatment.

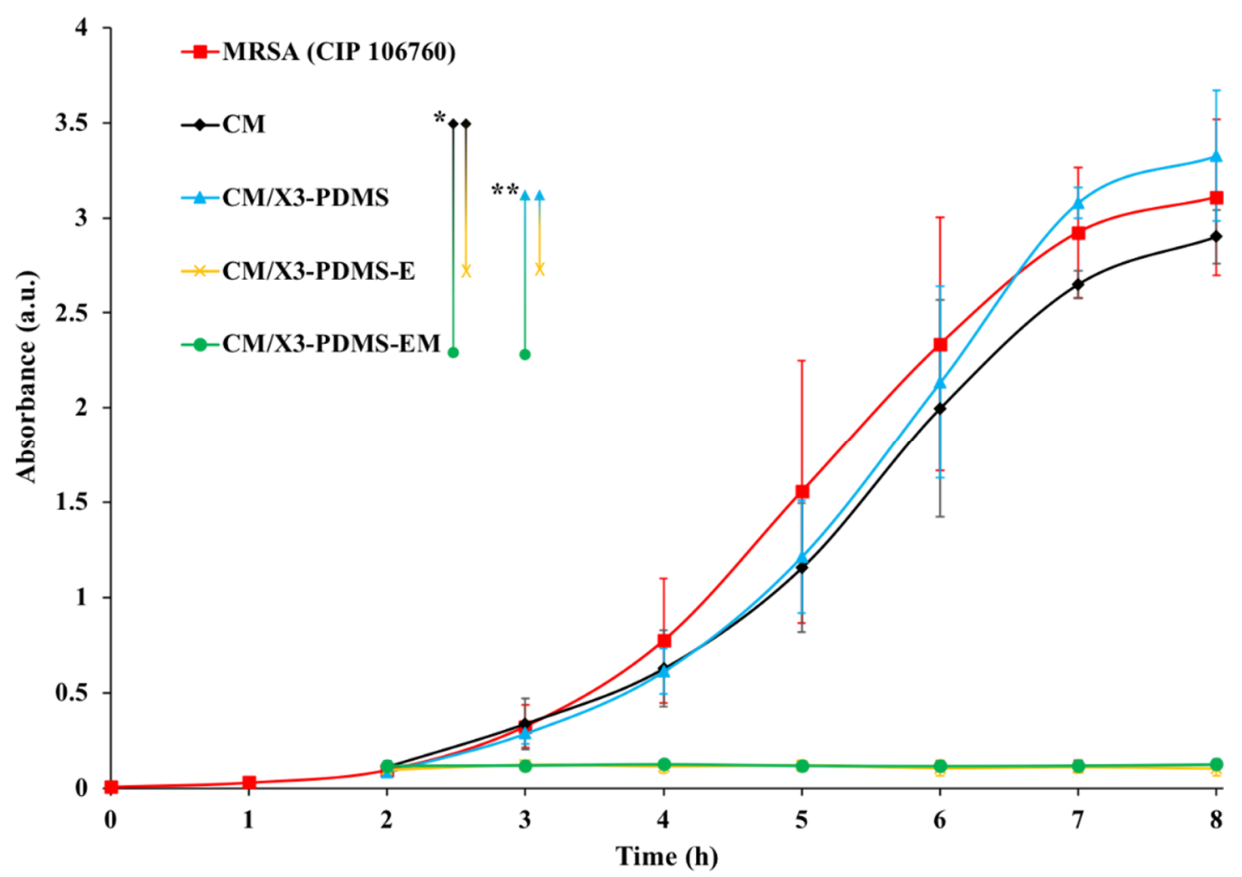

Figure 3. Antimicrobial activities against the bacteria methicillin-resistant S. aureus (MRSA), expressed by the optical density $\left(\mathrm{OD}_{620 \mathrm{~nm}}\right)$, obtained for uncoated $(\mathrm{CM})$ and coated monolithic filters (200 cpsi, $1.5 \mathrm{~cm} \times 1.5 \mathrm{~cm} \times 2 \mathrm{~cm}$ ) with polydimethylsiloxane-based coating: containing $0.56 \mathrm{wt}$. $\%$ of incorporated Econea (CM/X3-PDMS-E) or grafted Econea (CM/X3-PDMS-EM), and free of biocide (CM/X3-PDMS, control). The means \pm standard deviations (SDs) for three independent tests are presented. Statistical analysis was performed by the Friedman test and the differences are indicated with * $p<0.05$.

For the filters coated with biocidal polyurethane (PU)-based coatings containing incorporated Econea (CM/PU-E) and grafted Econea (CM/PU-EM), Figure 4, a higher inhibition of the MRSA growth was attained when compared to the free cultured bacteria (MRSA) or even with the filter coated with the pristine PU coating (CM/PU). Moreover, 
the differences between the coated filters containing Econea (incorporated or grafted) were evident, showing an expressed delay and subsequent MRSA growth decrease for the monolith coated with PU-based coating containing incorporated Econea (CM/PU-E) when compared with the one containing grafted Econea (CM/PU-EM), revealing that, for the grafting strategy, the delay and reduction in the bacterial growth are not as effective as for the incorporation strategy, which can be associated with the biocide immobilization strategy itself. The leaching strategy (CM/PU-E) released biocide into the culture media (Tables 2 and 3), and, under submersion conditions, a higher concentration of the biocide is expected at the outer coating film, and, under these conditions, more effective contact between the biocide and the bacteria was clearly promoted, thus, providing a higher antimicrobial efficacy. Nevertheless, a grafting strategy is still the most desirable approach to avoid the harmful effects associated with a release strategy and, most likely, an increase in the biocide content of the coating formulations would allow obtaining a similar antimicrobial effect for the grafting strategy, but, and to maintain its original properties, it will also require adjustments in the pristine commercial coating formulation and these adjustments go beyond the goal of this work.

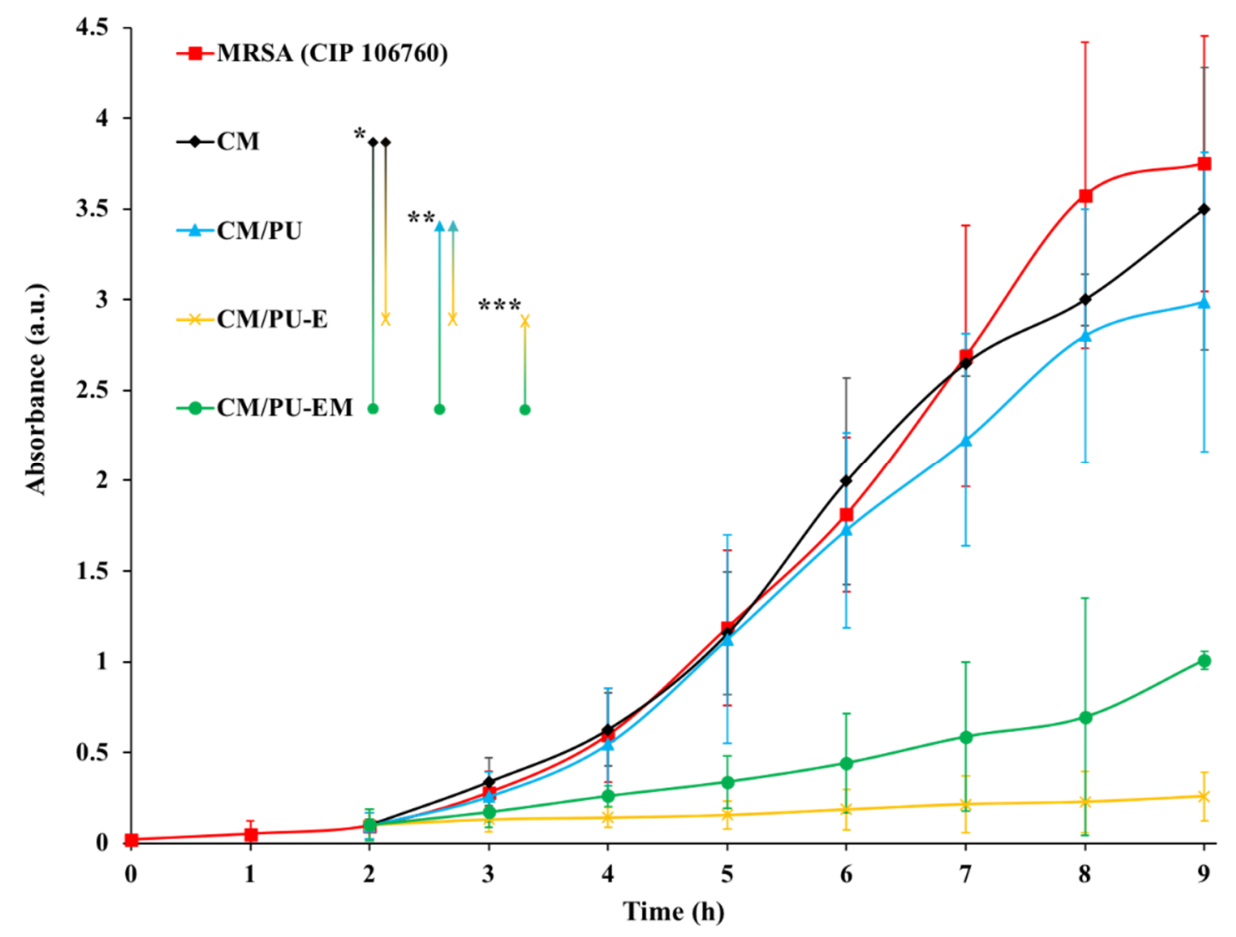

Figure 4. Effects of growth inhibition against the methicillin-resistant $S$. aureus (MRSA) expressed by the optical density $\left(\mathrm{OD}_{620 \mathrm{~nm}}\right)$, obtained for uncoated $(\mathrm{CM})$ and coated monolithic filters with pristine polyurethane (PU)-based coating (CM/PU) and containing $2 \mathrm{wt}$ \% of incorporated Econea (CM/PU-E) or grafted Econea (CM/PU-EM). The means \pm standard deviations (SDs) for three independent tests are presented. Statistical analysis was performed by the Friedman test and the differences are indicated with ${ }^{* *} p<0.01$.

\subsubsection{Biofilm Formation on Coated Substrates under Dynamic Conditions}

A dynamic biofilm formation assay was performed with $E$. faecalis with the aim of evaluating the antifouling activity of polyurethane coating formulations when exposed to shear forces typically found in water-based industrial systems (Figure 5). Both PU-modified coatings (PU-E and PU-EM) reduced biofilm formation compared to the pristine PU under flow conditions $(p<0.01)$. The number of biofilm cells expressed as CFU per $\mathrm{cm}^{2}$, was reduced on average by $60 \%$ after $48 \mathrm{~h}$, with the PU containing incorporated Econea (PU-E) being the most effective surface in reducing bacterial adhesion, with $72 \%$ inhibition when compared to PU. 


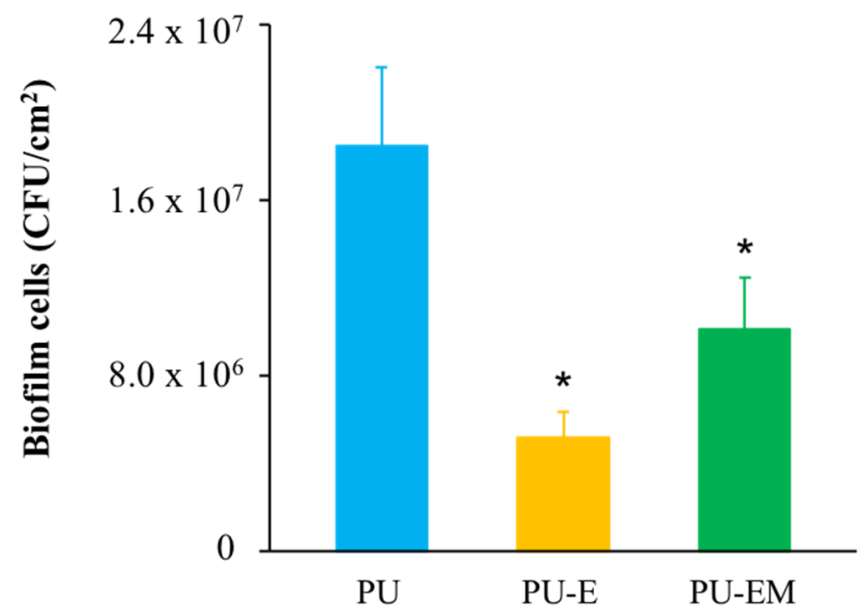

\section{Coated substrates}

Figure 5. Anti-biofilm performance of pristine polyurethane (PU)-based coating (control), and PU coatings containing incorporated (PU-E) and grafted Econea biocide (PU-EM) against Enterococcus faecalis under dynamic conditions. The means \pm standard deviations (SDs) for two independent experiments are presented. Statistical differences $(p<0.01)$ are pointed as * when each PU modified coating (PU-E or PU-EM) is different from the control.

Similar to the quasi-static tests of coated filters, the acrylic surfaces coated with biocidal polyurethane-based coatings also showed to be promising in preventing biofilm formation under dynamic conditions (Figure 5), regardless of how the Econea biocide was associated with the pristine coating (incorporated or grafted). However, the PU coating with incorporated Econea (PU-E) was more effective in reducing the biofilm CFUs than the PU coating with grafted Econea (PU-EM), which is in accordance with the results of antimicrobial susceptibility of PU-coated filters (Figure 4), and this may be related to the biocide immobilization strategy that was followed, as previously discussed.

Furthermore, to assess the contribution of the wettability properties (hydrophilicity/hydrophobicity) of the antimicrobial coatings, measurements of the water contact angle on the coatings are provided in Supplementary Figure S7. The PDMS-based coatings did not reveal significant differences in their wettability, despite their peculiar switchable behavior that changed from a highly hydrophobic $\left(100^{\circ}\right)$ into hydrophilic $\left(50^{\circ}\right)$ surface, associated with the intrinsic properties of the Hempasil X3+ commercial coating [46]. This coating is a hydrogel-based antifouling coating able to act in a dual-action mode, providing a fouling releasing effect (hydrophobicity), inferred by its low surface energy and relatively higher elasticity (low Young's modulus), and a hydrophilic character inferred by the hydrogel-polydimethylsiloxane matrix.

The PU-based formulations revealed stable hydrophobic behavior with contact angles ranging from $75^{\circ}$ to $85^{\circ}$, and without significant differences between the formulations with or without biocide, even for higher biocide contents ( $3 \mathrm{wt} . \%)$. These results suggest that the wettability of the coating formulations is not significantly affected by the presence of biocides for the tested contents, confirming that an antimicrobial improvement on those can be achieved upon biocide immobilization and with minimal interference on the original properties of the coatings, which agrees with previous work [24].

\section{Conclusions}

In this work, monolithic ceramic filters were coated, for the first time, with polydimethylsiloxane (PDMS) and polyurethane (PU)-based marine coatings containing grafted Econea, using an innovative non-biocide release strategy. The effectiveness of the grafted approach was demonstrated through the detection and quantification of the biocide released from the coated filters when submerged for periods of 45 days in water. A 9.22-fold reduction in the leaching of the biocide from PDMS-based coated filters containing $0.56 \mathrm{wt} . \%$ 
grafted Econea was attained, and no detectable biocide or derivatives were identified in the leaching waters obtained from the PU-based coated filters containing $2 \mathrm{wt} . \%$ of grafted Econea, suggesting complete immobilization of the biocide in the PU-based filters.

The coated filters also showed auspicious antimicrobial and bacteriostatic behaviors, providing complete growth inhibition on the biocidal PDMS-based filters, and inhibition effects as low as $66 \%$ on PU-based filters containing grafted Econea against the bacterium methicillin-resistant Staphylococcus aureus. Dynamic tests that simulate real aquatic conditions also showed promising results for the biocidal polyurethane (PU)-based coatings, with a $48 \%$ and $72 \%$ biofilm CFU reduction for the PU coating containing grafted and incorporated Econea, respectively, when compared to the PU reference coating.

These results are in line with those obtained in previous real field tests [24] that have already demonstrated the efficacy of both biocide-based coating matrices against marine biofouling, becoming a potential alternative antifouling strategy for water biodecontamination in aquatic systems, such as ballast water on ships, while minimizing the release of biocidal agents into the aquatic environment, and, therefore, contributing to the global search for sustainable and environmentally-friendly antifouling solutions to overcome the challenges of biofouling on industrial surfaces.

Supplementary Materials: The following are available online at https:/ / www.mdpi.com/2079-6 412/11/3/323/s1. Figure S1: Eco-friendly strategy to generate the isocyanate derivative of Econea biocide and promote its grafting in polymeric matrices; Figure S2: Antimicrobial activity of Econea biocide (b) and its isocyanate functionalized derivative (EM) (c) against MRSA (ATCC 33591) (a); Figure S3: Minimum bactericidal concentration (MBC) assay against methicillin-resistant Staphylococcus aureus (MRSA) for Econea biocide (E) (a), ranging from $500 \mu \mathrm{g} / \mathrm{mL}$ (E1) and $0.49 \mu \mathrm{g} / \mathrm{mL}$ (E11), and for the isocyanate functional derivative (EM) (b), ranging from $500 \mu \mathrm{g} / \mathrm{mL}$ (EM1) and $7.81 \mu \mathrm{g} / \mathrm{mL}$ (EM7). MRSA is a free bacterial culture assay without any established contact with the biocides; Figure S4: Antimicrobial susceptibility against MRSA and E. faecalis (Ef) bacteria of (a) pristine polyurethane (PU)-based coating (control) and PU-based coating containing grafted Econea biocide at different contents, 2 wt.\% (b) and 3 wt.\% (c); Figure S5: Base peak chromatograms from the analyses of leaching waters from monoliths (CM) coated with polyurethane (PU) and polydimethylsiloxane (PDMS)-based coatings with incorporated Econea (CM/X3-PDMS-E and CM/PU-E), grafted Econea (CM/X3-PDMSEM and CM/PU-EM), and biocide-free (CM/X3-PDMS and CM/PU): ESI (-) (a) and ESI (+) (b); Figure S6: Chemical structure of 4-bromo-2-(4-chlorophenyl)-5-(trifluoromethyl)-1H pyrrole-3carbonitrile (Econea) (a) and 3-bromo-5-(4-chlorophenyl)-4-cyano-1H-pyrrole-3-carboxylic acid (BCCPCA) (b); Figure S7: Contact angle measurements of water on polydimethylsiloxane (PDMS) and polyurethane (PU)-based marine coatings.

Author Contributions: Conceptualization, E.R.S.; methodology, F.J.M. and E.R.S.; formal analysis, O.F., R.S., S.M., R.G., M.G., and L.C.G.; investigation, O.F. and E.R.S.; resources, P.R., S.M., R.G., F.J.M., and E.R.S.; data curation, O.F., P.R., R.G., M.L.S., and E.R.S.; writing-original draft preparation, O.F. and E.R.S.; writing - review and editing, J.G., F.J.M., and E.R.S.; supervision, E.R.S. All authors have read and agreed to the published version of the manuscript.

Funding: This research work was supported by national funds through FCT-Foundation for Science and Technology within the scope of research units grants to BioISI (UIDB/04046/2020 and UIDP/04046/2020), and also by Base Funding-UIDB/00511/2020 of the Laboratory for Process Engineering, Environment, Biotechnology, and Energy-LEPABE-funded by national funds through the FCT/MCTES (PIDDAC). O. Ferreira also acknowledges the Grant PD/BD/128370/2017. L.C.G. and E.R.S. thank the Portuguese Foundation for Science and Technology (FCT) for their work contracts through the Scientific Employment Stimulus-Individual Call (CEECIND/01700/2017 and CEECIND/03530/2018).

Institutional Review Board Statement: Not applicable.

Informed Consent Statement: Not applicable.

Data Availability Statement: Data is contained within the article or Supplementary Materials.

Acknowledgments: The authors also thank HEMPEL A/S and Janssen PMP for the paints and biocide provision. 
Conflicts of Interest: The authors declare no conflict of interest.

\section{References}

1. Crittenden, J.C.; Trussell, R.R.; Hand, D.W.; Howe, K.J.; Tchobanoglous, G. MWH's Water Treatment Principles and Design, 3rd ed.; John Wiley \& Sons Inc.: Hoboken, NJ, USA, 2012. [CrossRef]

2. Heydarifard, S.; Pan, Y.; Xiao, H.; Nazhad, M.; Shipin, O. Water-resistant cellulosic filter containing non-leaching antimicrobial starch for water purification and disinfection. Carbohydr. Polym. 2017, 163, 146-152. [CrossRef] [PubMed]

3. Sharma, S.; Bhattacharya, A. Drinking water contamination and treatment techniques. Appl. Water Sci. 2017, 7, 1043-1067. [CrossRef]

4. Ruiz, G.M.; Rawlings, T.K.; Dobbs, F.C.; Drake, L.A.; Mullady, T.; Huq, A.; Colwell, R.R. Global spread of microorganisms by ships. Nature 2000, 408, 49-50. [CrossRef]

5. Fish, K.E.; Osborn, A.M.; Boxall, J. Characterising and understanding the impact of microbial biofilms and the extracellular polymeric substance (EPS) matrix in drinking water distribution systems. Environ. Sci. Water Res. Technol. 2016, 2, 614-630. [CrossRef]

6. Altug, G.; Gurun, S.; Cardak, M.; Ciftci, P.S.; Kalkan, S. The occurrence of pathogenic bacteria in some ships' ballast water incoming from various marine regions to the Sea of Marmara, Turkey. Mar. Environ. Res. 2012, 81, 35-42. [CrossRef]

7. Flemming, H.C.; Wingender, J. The biofilm matrix. Nat. Rev. Microbiol. 2010, 8, 623-633. [CrossRef] [PubMed]

8. Solon, K.; Volcke, E.I.P.; Spérandio, M.; Loosdrecht, M.C.M. Resource recovery and wastewater treatment modelling. Environ. Sci. Water Res. Technol. 2019, 5, 631-642. [CrossRef]

9. Ali, A.; Jamil, M.I.; Jiang, J.; Shoaib, M.; Amin, B.U.; Luo, S.; Zhan, X.; Chen, F.; Zhang, Q. An overview of controlled-biociderelease coating based on polymeric resin for marine antifouling applications. J. Polym. Res. 2020, 27, 1-17. [CrossRef]

10. Ng, C.; Chen, H.; Goh, S.G.; Haller, L.; Charles, F.R.; Wu, Z.; Trottet, A.; Gin, K.Y.H. Microbial water quality and the detection of multidrug resistant E. coli and antibiotic resistance genes in aquaculture sites of Singapore. Mar. Pollut. Bull. 2018, 135, 475-480. [CrossRef]

11. Ng, C.; Goh, S.G.; Saeidi, N.; Gerhard, W.A.; Gunsch, C.K.; Gin, K.Y.H. Occurrence of Vibrio species, beta-lactam resistant Vibrio species, and indicator bacteria in ballast and port waters of a tropical harbour. Sci. Total Environ. 2018, 610, 651-656. [CrossRef]

12. Maddah, H.; Chogle, A. Biofouling in reverse osmosis: Phenomena, monitoring, controlling and remediation. Appl. Water Sci. 2017, 7, 2637-2651. [CrossRef]

13. Noori, M.T.; Ghangrekar, M.M.; Mukherjee, C.K.; Min, B. Biofouling effects on the performance of microbial fuel cells and recent advances in biotechnological and chemical strategies for mitigation. Biotechnol. Adv. 2019, 37, 107420. [CrossRef] [PubMed]

14. Coetser, S.E.; Cloete, T.E. Biofouling and biocorrosion in industrial water systems. Crit. Rev. Microbiol. 2005, 31, $213-232$. [CrossRef]

15. Gu, J.-D. Biofouling and prevention: Corrosion, biodeterioration and biodegradation of materials. In Handbook of Environmental Degradation of Materials; William Andrew Publishing: New York, NY, USA, 2005; pp. 179-206. [CrossRef]

16. Nagaraj, V.; Skillman, L.; Li, D.; Ho, G. Review-Bacteria and their extracellular polymeric substances causing biofouling on seawater reverse osmosis desalination membranes. J. Environ. Manag. 2018, 223, 586-599. [CrossRef]

17. Chan, J.; Wong, S. Biofouling: Types, impact and anti-fouling. In Pollution Science, Technology and Abatement, 1st ed.; Nova Science Publishers Inc.: New York, NY, USA, 2010; ISBN 978-1-60876-501-0.

18. Lv, B.; Cui, Y.; Tian, W.; Wei, H.; Chen, Q.; Liu, B.; Zhang, D.; Xie, B. Vessel transport of antibiotic resistance genes across oceans and its implication for ballast water management. Chemosphere 2020, 253, 126697. [CrossRef]

19. Flemming, H.C. Microbial biofouling: Unsolved problems, insufficient approaches, and possible solutions. In Biofilm Highlights; Flemming, H.C., Wingender, J., Szewzyk, U., Eds.; Springer Publishing: Berlin/Heidelberg, Germany, 2011; Volume 5, pp. 81-109. [CrossRef]

20. Hammes, F.; Berney, M.; Wang, Y.; Vital, M.; Köster, O.; Egli, T. Flow-cytometric total bacterial cell counts as a descriptive microbiological parameter for drinking water treatment processes. Water Res. 2008, 42, 269-277. [CrossRef] [PubMed]

21. Batista, W.R.; Fernandes, F.C.; Lopes, C.C.; Lopes, R.S.C.; Miller, W.; Ruiz, G. Which ballast water management system will you put aboard? Remnant anxieties: A mini-review. Environments 2017, 4, 54. [CrossRef]

22. Lehaitre, M.; Compère, C. Biofouling and underwater measurement. In Real-Time Coastal Observing Systems for Marine Ecosystem Dynamics and Harmful Algal Blooms: Theory, Instrumentation and Modelling; Babin, M., Roesler, C.S., Cullen, J., Eds.; UNESCO Publishing: Paris, France, 2008; pp. 463-493, ISBN 978-92-3-104042-9.

23. Silva, E.R.; Bordado, J.C.M.; Ferreira, O.R.V. Functionalization Process for Biocide Immobilization in Polymer Matrices. Granted Patent PT108096B (WO2016/093719A1), 12 July 2019. Available online: https://patents.google.com/patent/PT108096B/en (accessed on 2 March 2021).

24. Silva, E.R.; Ferreira, O.; Ramalho, P.A.; Azevedo, N.F.; Bayón, R.; Igartua, A.; Bordado, J.C.; Calhorda, M.J. Eco-friendly non-biocide-release coatings for marine biofouling prevention. Sci. Total Environ. 2019, 650 Pt 2, 2499-2511. [CrossRef]

25. MacCullum, N.; Howell, C.; Kim, P.; Sun, D.; Friedlander, R.; Ranisau, J.; Ahanotu, O.; Lin, J.J.; Vena, A.; Hatton, B.; et al. Liquid-Infused silicone as a biofouling-free medical material. ACS Biomater. Sci. Eng. 2015, 1, 43-51. [CrossRef] [PubMed]

26. Zhang, Z.P.; Song, X.F.; Cui, L.Y.; Qi, Y.H. Synthesis of polydimethylsiloxane-modified polyurethane and the structure and properties of its antifouling coatings. Coatings 2018, 8, 157. [CrossRef] 
27. Lejars, M.; Margaillan, A.; Bressy, C. Fouling release coatings: A nontoxic alternative to biocidal antifouling coatings. Chem. Rev. 2012, 112, 4347-4390. [CrossRef] [PubMed]

28. Cao, S.; Wang, J.; Chen, H.; Chen, D. Progress of marine biofouling and antifouling technologies. Chin. Sci. Bull. 2011, 56, 598-612. [CrossRef]

29. Kriyzelr, S.; Kritzler, M. Biocidal Coating. PCT Patent Application WO 2013036996 A1, 21 March 2013. Available online: https:/ / patents.google.com/patent/WO2013036996A1/un (accessed on 2 March 2021).

30. Abe, Y.; Skali-Lami, S.; Block, J.C.; Francius, G. Cohesiveness and hydrodynamic properties of young drinking water biofilms. Water Res. 2012, 46, 1155-1166. [CrossRef]

31. Moreira, J.M.R.; Fulgêncio, R.; Oliveira, F.; Machado, I.; Bialuch, I.; Melo, L.F.; Simões, M.; Mergulão, F.J. Evaluation of SICON ${ }^{\circledR}$ surfaces for biofouling mitigation in critical process areas. Food Bioprod. Process. 2016, 98, 173-180. [CrossRef]

32. Teodósio, J.S.; Silva, F.C.; Moreira, J.M.R.; Simões, M.; Melo, L.F.; Alves, M.A.; Mergulhão, F.J. Flow cells as quasi-ideal systems for biofouling simulation of industrial piping systems. Biofouling 2013, 29, 953-966. [CrossRef] [PubMed]

33. Moreira, J.M.R.; Fulgêncio, R.; Alves, P.; Machado, I.; Bialuch, I.; Melo, L.F.; Simões, M.; Mergulhão, F.J. Evaluation of SICAN performance for biofouling mitigation in the food industry. Food Control. 2016, 62, 201-207. [CrossRef]

34. Kunze, A.; Pei, L.; Elsässer, D.; Niessner, R.; Seidel, M. High performance concentration method for viruses in drinking water. J. Virol. Methods 2015, 222, 132-137. [CrossRef]

35. Ferreira, O.; Rijo, P.; Gomes, J.F.; Santos, R.; Monteiro, S.; Vilas-Boas, C.; Correia-da-Silva, M.; Almada, S.; Alves, L.G.; Bordado, J.C.; et al. Biofouling inhibition with grafted Econea biocide: Toward a nonreleasing eco-friendly multiresistant antifouling coating. ACS Sustain. Chem. Eng. 2020, 8, 12-17. [CrossRef]

36. CLSI. Performance Standards for Antimicrobial Susceptibility Testing: Twenty-Fifth Informational Supplement; CLSI Document M100-S25; Clinical and Laboratory Standards Institute: Wayne, PA, USA, 2005; ISBN 1-56238-990-4.

37. OECD. Test No. 313: Estimation of Emissions from Preservative-Treated Wood to the Environment: Laboratory Method for Wooden Commodities that are not Covered and are in Contact with Fresh Water or Seawater. In OECD Guidelines for the Testing of Chemicals, Section 3; OECD Publishing: Paris, France, 2007. [CrossRef]

38. ISO 15181-1:2007. Paints and Varnishes-Determination of Release Rate of Biocides from Antifouling Paints. Part 1: General Method for Extraction of Biocides; ISO: Geneva, Switzerland, 2007.

39. Gomes, L.C.; Deschamps, J.; Briandet, R.; Mergulhão, F.J. Impact of modified diamond-like carbon coatings on the spatial organization and disinfection of mixed-biofilms composed of Escherichia coli and Pantoea agglomerans industrial isolates. Int. J. Food Microbiol. 2018, 277, 74-82. [CrossRef]

40. Teodósio, J.S.; Simões, M.; Melo, L.F.; Mergulhão, F.J. Flow cell hydrodynamics and their effects on E. coli biofilm formation under different nutrient conditions and turbulent flow. Biofouling 2011, 27, 1-11. [CrossRef]

41. Heath, R. Chapter 28-Isocyanate-Based Polymers: Polyurethanes, Polyureas, Polyisocyanurates, and their Copolymers. In Brydson's Plastics Materials, 8th ed.; Gilbert, M., Ed.; Butterworth-Heinemann: Oxford, UK, 2017; pp. 799-835, ISBN 978-0-32335824-8. [CrossRef]

42. French, G.L. Bactericidal agents in the treatment of MRSA infections-The potential role of daptomycin. J. Antimicrob. Chemother. 2006, 58, 1107-1117. [CrossRef]

43. Downs, R.A.; Dean, J.R.; Downer, A.; Perry, J.J. Determination of the biocide Econea ${ }^{\circledR}$ in artificial seawater by solid phase extraction and high performance liquid chromatography mass spectrometry. Separations 2017, 4, 34. [CrossRef]

44. Sharma, S.; Johnson, R.W.; Desai, T.A. XPS and AFM analysis of antifouling PEG interfaces for microfabricated silicon biosensors. Biosens. Bioelectron. 2004, 20, 227-239. [CrossRef]

45. Zhang, X.; Brodus, D.S.; Hollimon, V.; Hu, H. A brief review of recent developments in the designs that prevent biofouling on silicon and silicon-based materials. Chem. Cent. J. 2017, 11, 1-12. [CrossRef]

46. Hempel Product Data HEMPASIL X3+ 87500; Hempel: Lyngby, Denmark, 2016. 